\title{
Between Foucault and Agamben: An Overview of the Problem of Euthanasia in the context of Biopolitics ${ }^{\left[{ }^{*}\right]}$
}

\section{Foucault ile Agamben Arasında: Biyopolitika Bağlamında Ötenazi So- rununa Bir Bakıș}

GÜRHAN ÖZPOLAT

Dokuz Eylül University

Received: 07.06.2017 | Accepted: I8.12.2017

\begin{abstract}
In this paper, considering the fact that special forms of dying and killing are mostly seen in a shadowy zone or blurred boundary between life and death, I shall attempt to find a compromise between Michel Foucault (biopolitics) and Giorgio Agamben's (thanatopolitics) considerations of biopolitics in the case of euthanasia. In this respect, believing that this article requires a historical backround, I shall start with a brief history of euthanasia and suicide in order to understand the present juridico-medico-political complex from which the sovereign power derives its philosophical underpinnings and theoretical justifications today; and show that the relationship power and death has always been very problematic. Secondly, I will focus on the meaning(s) of the disappearance of death in the context of Foucauldian biopolitics and conclude that, in contrast to Foucault's consideration, something akin to re-discovery of death has taken place in the Western world since the mid-twentieth century. Finally, in the third and last part of the article, I will put forward that Agamben, by introducing the concept life unworthy of being lived, was successful in completing what is missing, that is the politics of death, in Foucault's notion of biopolitics with reference to the problem of euthanasia.
\end{abstract}

Keywords: Assisted suicide, death, euthanasia, biopolitics, thanatopolitics, power, sovereignty.

(C) Özpolat, G. (2017). Between Foucault and Agamben: An Overview of the Problem of Euthanasia in the context of Biopolitics. Beytulhikme An International fournal of Philosophy, 7 (2), 15-31.

凶 Gürhan Özpolat, Arș. Gör.

Dokuz Eylül Üniversitesi İİBF Kamu Yönetimi Bölümü

3516o, Buca, İzmir, TR | gurhanozpolat@gmail.com 


\section{Introduction}

The concept death has consistently remained a matter of academic interest and has largely been discussed by many disciplines from philosophy to sociology, anthropology to psychology and literature to theology. Since death is an inevitable and a common experience not only for human beings but also all living creatures, its considerable effects on the daily life practices can be seen as an explicit social phenomenon in every culture. Yet, among all living creatures, human kind has a place apart, the final, extreme place in relation to death. Unlike other living beings, he has a more fundamental relationship with death since he invented the special forms of killing and dying, in our case, euthanasia. ${ }^{\mathrm{I}}$

In this paper, considering the fact that special forms of dying and killing are mostly seen in a shadowy zone or blurred boundary between life and death, I am going to attempt to find a compromise between Michel Foucault (bio-politics) and Giorgio Agamben's (thanatopolitics) considerations of biopolitics in the case of euthanasia. I believe that euthanasia is a perfect example of the modern biopolitical dispositif in which, in a Foucauldian sense, the separation between taking life and letting die loses its meaning and falls into a zone of indistinction. Moreover, the problem of euthanasia gives us a chance to re-think not only the Foucauldian notion of biopolitics but also Agamben's conceptualization. Since euthanasia is not a radical break from the classical biopolitical dispositif, but rather, it discloses the function and foundation of modern biopolitics in a more radical way. Euthanasia signals the point at which the biopolitical dispositif passes beyond a new threshold and turn into thanatopolitics.

I am going start with a brief history of euthanasia and suicide in order to understand the present juridico-medico-political complex from which the sovereign power $^{2}$ derives its philosophical underpinnings and

I I would like to point out that by the term euthanasia, I do not make a difference between physician-assisted suicide, voluntary euthanasia, non-voluntary euthanasia and active or passive euthanasia.

2 I am going to use the term sovereignty as a combination of 'power over life' and 'power over death' (Foucault, 2003a: 259; Agamben, 1998: 159). However, I do not intend to make a strict separation between biopolitics and thanatopolitics as if they are totally disconnected from each other; but rather, my intention is to simplify the relationship between them in order to show how these concepts can provide theoretical underpinnings in order to understand the problem of euthanasia. I believe that biopolitics and thanatopolitics 
theoretical justifications today. I believe that it is necessary to examine, in the first place, the historical conditions in which euthanasia emerged. It is also necessary to situate the issues of euthanasia and suicide within their historico-political context by examining the relationship between power and death; in other words, political power's attitude toward death ${ }^{3}$ and special forms of dying in order to understand which medicohistorico-political processes caused the present juridico-political discourse about euthanasia and suicide in which we live today. Secondly, I will focus on the meaning(s) of disappearance of death in the context of Foucauldian biopolitics and conclude that, in contrast to Foucault's consideration, something akin to re-discovery of death has taken place in the Western world since the mid-twentieth century. Finally, I am going to introduce the Agambenian concept life unworthy of being lived in order to complete what is missing, or, at least, implicit that is the politics of death, in Foucault's notion of biopolitics with reference to the problem of euthanasia.

\section{A Brief History of Attitudes toward Euthanasia and Suicide in the West}

The problem of euthanasia once again became a matter both in medical, legal and political theories, when the former doctor Maurice Genereux was sentenced to jail for two years in May 1998, and became the first physician to be convicted of assisted suicide in the history of North America. Despite the fact that euthanasia started to become legalized in some of the European countries, such as Switzerland, the Netherlands, Belgium at the beginning of 2000 (Burkhardt, La Harpe, Harding \& Sobel, 2006: 287-294), the issue of euthanasia is not a contemporary problem; it has always been a part of human culture and societies since the beginning (Ryan, Morgan \& Lyons, 20II: 44).

In ancient times, euthanasia was defined as a form of suicide in which a physician allows his patient to die due to their suffering from an incurable, painful disease or medical condition. It is important to say that in the ancient sense of euthanasia the main emphasis was not on the act

are not totally different concepts but two sides of the same coin. Death exists as a political phenomenon at the point where biopolitics and thanatopolitics meet.

3 Despite the fact that the attitudes toward death varied from the East to the West, in this paper, merely the Western attitudes toward death and euthanasia will be examined. 
of killing but dying. Similar to the modern form of assisted suicide, the physician did not kill the patient but prepared the conditions in which he can commit suicide in antiquity. In this respect, euthanasia can also be considered as a 'relation of abandonment' (Agamben, I998) or 'letting die' (Foucault, 2003a). Therefore, the history of euthanasia is also a part of the history of the attitudes toward suicide in Western tradition. In this respect, it can be said that the relationship between political power and suicide had always been very problematic since ancient times (Gillon, I969: I74).

According to Amundsen, in ancient Greece, except suicide of slaves and soldiers, suicide was defined as a crime requiring a legal sanction by law (Amundsen, I978: 934). In addition to this, there were some disrespectful cultural implementations in ancient Greece that applied to the corpse of person who committed suicide. For example, in Attica, it was common to amputate the right hand of the corpse and bury it in another place apart from the body (Gillon, 1969: 176). However, this kind of humiliating implementations to the dead body showed the reflections of the belief system rather than the strength of criminal sanction. Despite the lack of a powerful central administration and governmental technologies in ancient Greece, socio-cultural and moral complexes concerning make live were present. In other words, similar to the Christian era, in ancient times, the socio-political structure and belief system was built upon a complex that did not allow people to throw their lives away.

Yet, it is remarkable to say that whatever general attitude was taken to suicide in the ancient era, it was always acceptable in the cases of incurable disease before Christianity. Even those ancient Greek philosophers, such as Pythagoras, Plato and Aristotle, who radically rejected suicide, accepted that there was nothing wrong with ending a life which had become unendurable to live (Gillon, I969: 174). Moreover, not only the Greek but also the Roman thinkers had a common understanding of euthanasia, and accepted suicide in some circumstances. In the light of this content, it can be concluded that ancients were fairly permissive about suicide and euthanasia in the cases of incurable and fatal disease. In spite of the fact that there are some indications that people confronted few problems finding a physician to provide them with assistance dying, 
it can be said that the majority of requests for euthanasia or assisted suicide were fulfilled in both ancient Greece and Rome (Dowbiggin, 2007: 9-IO).

With the rise of Christianity, suicide and euthanasia once again started to become a matter in the third century. Especially, because of the neo-Platonist school of Plotinus's argument, "that it perturbed the soul and delayed its passage to the after-life", against any form of suicide, finally, caused to prohibition of euthanasia and suicide. Gillon notes that "over the next few hundred years various ecclesiastical punishments were prescribed and popular barbarities to the suicide's body became more repulsive" (Gillon, I969: I76-I77).

During the long period from the early middle age to the Enlightenment, the attitudes toward suicide and death remained almost same in the West. As Foucault states, "with the coming of the Enlightenment, death, [once again] was entitled to the clear light of reason, and became for the philosophical mind an object and source of knowledge" (Foucault, 2003b: 125). In spite of the fact that the Enlightenment movement could disentangle "the philosophical consideration of suicide" from the dogma of theology (Gillon, 1969: 177), it could not prevent 'life' from becoming a victim of a new power technology which emerged in the late eighteenth century. Yet, developments in modern bio-medical technologies and invention of life-support machines in the I950s caused a necessity for redefining death (Lamb, I985: I6-I9; Agamben, I998: I60-I6I). It is precisely for this reason that death and special forms of dying have become once again a controversial juridico-political debate since the mid-twentieth century.

2. The Meaning of Disappearance of Death in the context of the Foucauldian Biopolitics

Death has mostly been understood as the absence of life but what is the political meaning of the concept death? Michel Foucault is one of the pioneer thinkers who attempted to respond this question linking the concept death with the problem of power in his works. In Society Must Be Defended, focusing on the historico-political conditions in which life became the concern of governmental technologies in the nineteenth centu- 
ry, he describes the processes and socio-political transformations in which "the great public ritualization of death" started to disappear (Foucault, 2003a: 247). Foucault claims that in the late eighteenth century death started to become a phenomenon that must be hidden away in the public sphere. According to him, thanks to a power technology concerning 'to make live', "death was no longer something that suddenly swooped down on life [...], death was now something permanent, something that slips into life, perpetually gnaws at it, diminishes it and weakens it" (Foucault, 2003a: 244). For Foucault, "a concrete manifestation of this power" was the "disqualification of death" (Foucault, 2003a: 247) and death started to be considered as a "shameful" and "forbidden" phenomenon during the nineteenth century (Ariés, I974: 85). Foucault notes:

I think that the reason why death had become something to be hidden away is not that anxiety has somehow been displaced or that repressive mechanisms have been modified. What once (and until the end of the eighteenth century) made death so spectacular and ritualized it so much was the fact that it was a manifestation of a transition from one power to another. Death was the moment when we made the transition from one power-that of the sovereign of this world - to another-that of the sovereign of the next world. A transition from one power to another (Foucault, 2003a: 247).

Foucault argues that the disappearance of death was a result of the emergence of biopower in the late eighteenth century. In contrast to the former power model in which the sovereign has 'the right to take life or let live; with the emergence of biopower, political power started to avoid taking life and become concerned with 'mak[ing] live'. ${ }^{4}$ Foucault puts forward that throughout this transformation in the power mechanisms, man has started to be considered as 'a species' or 'living being' instead of a

4 In The History of Sexuality and Society Must Be Defended, Foucault focuses on the historical conditions in which life became the concern of political and economic calculations in the late eighteenth century. According to him, with the emergence of bio-power in this era 'the biological existence' (Foucault, 1984: 264) of the human body politicized through a set of administrative techniques and statistical knowledge concerning "the longevity and productivity of life", "the level of health" and "life expectancy" (Foucault, I978: 139). For Foucault, this was a sign of a great political transformation in which the old sovereign power and its basic characteristics were replaced by this new power technology and its biopolitical rationality. The main thesis Foucault defends is, in contrast to the classical power model in which the sovereign has "the right to take life or let live"; in the era of biopolitics political power's function is 'to make live and let die' (Foucault, 2003a: 24O-4I). 
'legal subject' for the first time in history (Foucault, 2003a: 240-242):

Power would no longer be dealing simply with legal subjects over whom the ultimate dominion was death, but with living beings, and the mastery it would be able to exercise over them would have to be applied at the level of life itself; it was the taking charge of life, more than the threat of death, that gave power its access even to the body (Foucault, 2003a: 265).

In this respect, to Foucault, biopower wants to make live due to the fact that death is beyond its power. As Arendt draws attention, "nobody can rule over dead men" (Arendt, I998: 20I). "Death is power's limit, the moment that escapes it; death becomes the most secret aspect of existence, the most private" (Foucault, 1984: 26I). Death is that absolute boundary for which there is neither life nor power:

Death is outside the power relationship. Death is beyond the reach of power, and power has a grip on it only in general, overall, or statistical terms. Power has no control over death, but it can control mortality. And to that extent, it is only natural that death should now be privatized, and should become the most private thing of all. In the right of sovereignty, death was the moment of the most obvious and most spectacular manifestation of the absolute power of the sovereign; death now becomes, in contrast, the moment when the individual escapes all power, falls back on himself and retreats, so to speak, into his own privacy. Power no longer recognizes death. Power literally ignores death (Foucault, 2003a: 247-248).

In fact, Foucault is not the first thinker who problematized the disappearance of death. When he highlighted the processes in which death started to disappear from the public rituals, the idea of the disappearance of death had already become a matter of both philosophical and sociological interest due to the fact that the scholars, such as Becker (1973) and Ariés (I974), pointed out 'the denial of deatb' in the nineteenth century. Similar to Becker and Ariés, Joseph Jacobs (1899) introduced a provocative article with an aphoristic title The Dying of Death, which appeared in Fortnightly Review, in which he ascribes the disappearance of feelings and thoughts about death. According to Jacobs, throughout the nineteenth to twentieth century, death started to be considered as the object of taboo in daily life practices. 
However, as is discussed in the first section, these kinds of cultural and biopolitical considerations toward death, especially, in the case of suicide, were also a characteristic of classical antiquity. Death has always been seen as an enemy to be combated in the West. The traces of this consideration can be seen at the level of the attitudes toward suicide. In the light of this content, it can be said that Foucault seems to overlook the presence of a socio-cultural complex concerning, in a simple sense, 'make live' since antiquity. Focusing on the producing of the normality at the level of power mechanisms and considering biopolitics as a new invention and consequence of modern power technologies, Foucault does not realize the fact that "biopolitics is something like the secret truth of all western politics, law and political philosophizing" (Blencowe, 20ı: II5). As Agamben argues, the biological existence of the human body, human as a 'species' or 'living body' always existed in the West. Sovereign power's central concern had been not only life but also death since the beginning. In light of this, Foucault simply gravitated toward the biopolitical discourse of modernity that drove death to "the fringes of culture" and made it "abnormal" (Bleakley \& Bligh: 2009: 379). In contrast to Foucault's consideration, death was not merely "in the eighteenth-century medical thought" but was always "the absolute fact and the most relative of phenomena" (Foucault, 2003b: I40) since the beginning. Therefore, Foucault was mistaken not only for considering biopolitics as if it is an invention of modern politics and consequence of modern power mechanisms but also associating Western attitude toward death as if it is merely a characteristic of modernity.

To sum up, despite the fact that Foucault analyses the rise of modern medicine in relation to death in The Birth of Clinic and ascribes the political meaning of death in Society Must Be Defended and The History of Sexuality; he "does not set out to prospectively consider how medicine and death are related in an era of ' $h i g h$-tech' possibilities, in which lifesupport machinery [...] offers an important extension of a doctor's practical skill” (Bleakley \& Bligh: 2009: 374). In spite of his awareness of modern bio-medical technologies that can "keep people alive when, in biological terms, they should have been dead long ago" (Foucault, 2003a: 248); he underestimates the capacity of sovereignty to kill in relation to biopol- 
itics. Moreover, his special interest in the late eighteenth and nineteenth centuries' biopolitical dispositif, that emphasizes the political economy of life, does not allow him to account the importance of the political economy of death in the context of modern biopolitics. Foucault, in contrast to Agamben, is more interested in the other side of the coin, 'life' rather than 'death'. Therefore, as Agamben puts forward, there are "blind spot(s)" in the conceptualization of Foucault's biopolitics, that "have to be corrected, or, at least, completed" (Agamben, I998: 6-9). In contrast to Foucault's consideration, death is now no longer a taboo; it is even possible to mention 'the revival of death' (Walter, I994) rather than 'the denial of death' (Freud, I9I8: 57; Becker, I973; Ariés, 1974; Dollimore, 200I). As Bleakley and Bligh said: "death is now everywhere" (Bleakley \& Bligh, 2009: 380).

\section{Beyond the Boundaries of the Classical Biopolitics: Euthanasia and Thanatopolitics}

Both political and social theorists, thanks to Foucault, have been focusing on the administration of life (Foucault, 1978: 138) -the politics of life itself or the politicization of life (Agamben, I998: II9-I25) - since the second half of the twentieth century. Concentrating on the sociopolitical and historical conditions in which 'legal subjects' could gain a biopolitical existence, Foucault was more interested in the government of life rather than death or dying practices. Although he problematized the concept death in relation to biopolitics during his lectures in Collège de France (Foucault, 2003a: 247-254), to use merely his approach in the context of modern biopolitics might be insufficient to grasp the complete meaning of the politics of death and different forms of dying such as abortion, euthanasia, death camps, suicide bombers and so on. Thus, it can be helpful to make a distinction between power over life and power over death in order to figure out the juridico-medico-political practices of sovereign power over both life and death. In contrast to the Foucauldian consideration of biopower, "the biopolitical dispositif does not replace sovereignty", but rather, "it displaces its function and renders the problem of its foundation even more acute" (Lazzarato, 2002: IO4). ${ }^{5}$

5 According to Agamben, as opposed to Foucault's thesis, it is not possible to mention a 
If we give the name 'politicization of death' or 'politicizing death' (Agamben, I998: I60-165) to the relationship between political power and special forms of dying, in our case euthanasia, which represents itself both in the form of 'kill[ing] without committing homicide' (Agamben, I998) and 'letting die' (Foucault, 2003a), then we should, on the one hand, find out the answer of the Foucauldian query ${ }^{6}$ concerning the condition of possibilities of killing and letting die in relation to political power (Foucault, 2003a: 254). On the other hand, we should re-consider Foucault's significant questions by taking into account of Agamben's, Homo Sacer $(\text { I998 })^{7}$ in order to disclose the ambiguous boundaries of sovereign power

sharp politico-historical shift away from the classical sovereign power to bio-power. Instead, putting the concept 'bare life' into a modern and wider political framework, he claims that modernity has merely generalized and radicalized the Schmittian concept 'the state of exception' which has been simply there from the beginning (Agamben, I998: II2; Mills, 2008: 65, Lemke, 20II: 53). Thus, it can be said that the main difference between Foucault and Agamben lies in their consideration of biopolitics: whereas Foucault replaces "bio-power" by "old sovereignty", Agamben combines them together "by equating Foucault's 'control over life' with Carl Schmitt's state of exception" (Rancière, 2004: 300).

${ }^{6}$ In Society Must Be Defended, Foucault asks the following questions in order to test the concept of bio-power in the context of death (Foucault, 2003a: 254): "If it is true that the power of sovereignty is increasingly on the retreat and that disciplinary or regulatory disciplinary power is on the advance, how will the power to kill and the function of murder operate in this technology of power, which takes life as both its object and its objective? How can a power such as this kill, if it is true that its basic function is to improve life, to prolong its duration, to improve its chances, to avoid accidents, and to compensate for failings? How, under these conditions, is it possible for a political power to kill, to call for deaths, to demand deaths, to give the order to kill, and to expose not only its enemies but its own citizens to the risk of death?" Although he lays the foundations for the discussion of biopower and biopolitics by putting these questions into a game of truth, he does not have the same success in responding them. As such, it is possible to say that "Foucault's concept of biopower sits uneasily astride" (Patton, 2007: 2I4) with the concept of death and especially in the case of special forms of dying, such as death camps, euthanasia, assisted suicide, suicide bombers and so on.

7 In Homo Sacer, Agamben opens by drawing attention to the distinction between " $z o \vec{e}$ " and "bios" which defines two different aspects of 'life' in ancient Greek. Whereas "zoe expressed the simple fact of living common to all living beings (animals, men, or gods), and bios, [...] indicated the form or way of living proper to an individual or a group" (Agamben, 1998: I). Pointing out the distinction between life as 'the fact of living' and 'the way of life' (form-of-life), Agamben claims that Foucault was mistaken for considering biopolitics as if it is an invention of modern political theory and consequence of modern power technologies. In contrast to Foucault, he believes that "biopolitics is something like the secret truth of all western politics, law and political philosophizing" (Blencowe, 20IO: II5). Placing the biopolitical paradigm at the centre of the Western political tradition, he explicitly states that Foucault's concept of 'the biological existence of the buman body', human as a 'species' or 'living being' had already been included the Western politics as "bare life", which has been produced by sovereign power- since Ancient Greece. Therefore, he puts forward the idea that there are 'blind spot(s)' in the Foucauldian sense of biopolitcs that 'bave to be corrected, or, at least, completed (Agamben, 1998: 6-9). It is precisely for this reason that, ta- 
in relation to life and death: How can it be possible to kill for a political power that wants to make live in the case of euthanasia? How does the power over life and death function in a political order that is built upon the dogma of the sacredness of life by means of euthanasia?

At this point, in my opinion, Agamben's relevance ${ }^{8}$ is clear by introducing a concept, 'life unworthy of being lived'. Agamben, responding to the questions above in his magnum opus, Homo Sacer, shows how the problem of euthanasia extends the boundaries of the classical biopolitical dispositif:

The concept of life unworthy of being lived is clearly not an ethical one, which would involve the expectations and legitimate desires of the individual. It is, rather, a political concept in which what is at issue is the extreme

king the concept of 'bare life' or 'sacred life' at the centre of his inquiry, he simply attempts to combine Arendt and Foucault's points of view. Agamben notes that throughout a process of 'exclusion in the form of inclusion', 'naked life', or, in the Foucauldian sense, the biological existence of the human body has long been politically surrounded by sovereign power. He, even, cites that "the production of a biopolitical body is the original activity of sovereign power" (Agamben, 1998: 6). In this sense, what modern power does is to place the concept 'naked life' at the centre of political calculations as well as political strategies in a more radical way.

${ }^{8}$ By stating "bare life" has always been "at the heart of sovereign power", Agamben draws attention to "a hidden link" between sovereignty and the biological existence of humans which already exists (Patton, 2007: 213). Moreover, according to Patton (2007), Agamben believes that he succeeded in "correction" or, at least, "completion" of Foucault, showing that the production of "bare life" has been a crucial activity of sovereignty its beginnings. Yet, for Genel (2006: 45), "the synthetic aim of his project does not appear ultimately to accomplish this task". From this point of view, Agamben rather than attempting, as he states, "to correct or, at least, complete" the Foucauldian thesis on biopolitics; so to speak, completely turns Foucault on his head and goes his own way by claiming that the Foucauldian term biopolitics, as an "original - if concealed - nucleus of sovereign power" has long been a crucial aspect of the sovereignty: "production of a biopolitical body is the original activity of sovereign power" (Agamben, I998: 9, 6). Agamben by overturning the Foucauldian consideration of biopolitics in relation to sovereign power builds his own theory on the Foucauldian term biopolitics; yet, it is important to say that "Agamben's analysis is more indebted to Carl Schmitt than to Michel Foucault" (Lemke, 2005: 9). Moreover, he is more under the influence of the Aristotelian and Heideggerian ontology as well as Hannah Arendt and Walter Benjamin's "theoretical arsenal" rather than Foucault's intellectual legacy (Orford, 2007: 208-209; Mills, 2008: 59-60). Agamben, in contrast to Foucault, is more interested in the other side of the coin, 'death' instead of 'life': whereas Foucault problematizes the production of norms and 'normal conditions' in the context of biopolitics, Agamben focuses on 'zones of indistinction' and 'the state of exception' in which legal norms were suspended by the sovereign power (Lemke, 20II: 60). Thus, Agamben "is interested not so much in 'life' as in its 'bareness", and therefore, "the question of biopower" is not a "central concern" of him; but "the body's capacity to be killed" is what he concerns (Genel, 2006: 44, Lemke, 2011: 59, Agamben, 1998: 125). Therefore, as opposed to the Foucauldian consideration of the term, for Agamben, biopolitics is above all politics of death (Fitzpatrick, 200I: 263-265). 
metamorphosis of sacred life - which may be killed but not sacrificed - on which sovereign power is founded. If euthanasia lends itself to this exchange, it is because in euthanasia one man finds himself in the position of having to separate $z o \bar{e}$ and bios in another man, and to isolate in him something like a bare life that may be killed. From the perspective of modern biopolitics, however, euthanasia is situated at the intersection of the sovereign decision on life that may be killed and the assumption of the care of the nations biological body. Euthanasia signals the point at which biopolitics necessarily turns into thanatopolitics (Agamben, 1998: 142).

It is remarkable to say that Agamben takes no ethical position on the problem of euthanasia: "it is not our intention here to take a position on the difficult ethical problem of euthanasia, which still today, in certain countries, occupies a substantial position in medical debates and provokes disagreement". What Agamben does is merely, linking the problem of euthanasia with sovereign power, to point out the zone of indistinction in which power over life turns to power over death and to explore the politics of euthanasia as a state policy:

More interesting for our inquiry is the fact that the sovereignty of the living man over his own life has its immediate counterpart in the determination of a threshold beyond which life ceases to have any juridical value and can, therefore, be killed without the commission of a homicide (Agamben, I998: I39)

It is also important to say that, in this respect, Agamben by the term euthanasia only considers active euthanasia, in which the physician does something that causes the patient to die, and refers to a Nazi biopolitician's pamphlet which points out, according to Agamben, "the fundamental biopolitical structure of modernity -the decision on the value (or nonvalue) of life-" and signals at the point in which "the decision on life becomes a decision on death" (Agamben, I998: 137, 122). However, either in the form of assisted dying or in the form of killing, the distinction between 'taking life' and 'letting die' losses its meaning politically and the patient falls into a "zone of indistinction between the animal and the human" (Agamben, 1998: 107). In a grey zone where life has no value and thus may be killed, bare life and political life are bound together. In the case of euthanasia a patient becomes a sacred man, who may be killed and 
yet not sacrificed due to the fact that he does not deserve to live anymore. Even when euthanasia was forbidden in the manner of law in some of the Western countries, physicians who help their patient to commit suicide was not sentenced in some cases (İnceoğlu, 1999). This example clearly supports Agamben's claim:

The sovereign sphere is the sphere in which it is permitted to kill without committing homicide and without celebrating a sacrifice, and sacred life that is, life that may be killed but not sacrificed - is the life that has been captured in this sphere (Agamben, 1998: 83).

On the other hand, in some cases patients cannot be helped to commit suicide or killed, even if they desperately want to die, as in the case of Diane Pretty, who was suffering from an incurable and fatal disease and wanted her husband to end her life without being prosecuted for aiding and abetting suicide (Szerletics, 20II: 479-496). At this point, we confront a power/knowledge complex, a combination of different power/knowledge regimes, such as law, medicine and politics that decide which life does deserve to live and which one is unworthy of being lived. In this respect, sovereign's decision on life becomes two shapes: who may live and who must die. Either in the form letting die or killing without committing homicide, euthanasia points out the capacity of sovereignty to kill. In the light of this content, not only the integration of medicine and politics (Agamben, I998: I43) but also law can be seen as one of the main characteristics of modern biopolitics. The combination of these three disciplines is applied both at the level of the individual body and the whole population by sovereign power.

\section{Conclusion}

I have tried to discuss a brief history of euthanasia and suicide in order to figure out the present juridico-medico-political complex from which the sovereign power derives its philosophical underpinnings and theoretical justifications and showed the fact that the relationship between death and political power has always been problematic. Secondly, I have focused on the meaning(s) of disappearance of death in the context of Foucauldian biopolitics and attempted to discuss that rather than disappearance or denial of death, something very similar to re-discovery of 
death has started to take place in the Western world since the midtwentieth century. Finally, I have situated the Agambenian concept 'life unworthy of being lived' (I998: 136-I43) in the debate biopolitics in order to show the zone of indistinction which biopolitics turns to thanatopolitics. As Agamben puts forward, it is not possible to mention a radical politicohistorical break from the classical sovereign power to biopower. Euthanasia as a political phenomenon signals the shadowy zone where power over life and power over death meet. Euthanasia is a perfect example of the modern biopolitical dispositif in which, in a Foucauldian sense, the separation between 'taking life' and 'letting die' loses its meaning. As Agamben realized, not only life but also death is political, and euthanasia can be considered as an example that discloses the function and foundation of modern biopolitics maybe in a more acute way. From this point, it is possible to say that Agamben by introducing a concept, life that does not deserve to live with reference to the problem of euthanasia, completes what is missing, or, at least implicit in the Foucauldian sense of biopolitics.

\section{References}

Agamben, G. (1998). Homo Sacer: Sovereign Power and Bare Life. Stanford: Stanford University Press.

Amundsen, D. (1978). History of Medical Ethics: Ancient Greece and Rome. Encyclopedia of Bioethics, vol. 3 (ed. W. T. Reich). New York: Free Press, 930937.

Arendt, H. (1998). The Human Condition. Chicago: The University of Chicago Press.

Ariés, P. (1974). Western Attitudes toward Death: From the Middle ages to the Present. Baltimore and London: The Johns Hopkins University Press.

Becker, E. (1973). The Denial of Death. London: The Free Press.

Bleakley, A. \& Bligh, J. (2009). Who Can Resist Foucault? Fournal of Medicine and Philosophy, 34, 368-383

Blencowe, C. (20I0). Foucault's and Arendt's 'Insider View' of Biopolitics: A Critique of Agamben. History of the Human Sciences, 23 (5), II3-I3O. 
Burkhardt, S.; La Harpe, L.; Harding, T-W. \& Sobel, J. (2006). Euthanasia and Assisted Suicide: Comparison of Legal Aspects in Switzerland and Other Countries. Medicine, Science and Law, 46 (4), 287-294.

Dollimore, J. (200I). Death, Desire and Loss in Western Culture. New York: Routledge.

Dowbiggin, I. (2007). A Concise History of Euthanasia: Life, Death, God, and Medicine. New York: Rowman \& Little Field Publishers.

Freud, S. (1918). Reflections on War and Death. New York: Moffat, Yard \& Co.

Fitzpatrick, P. (200I). These Mad Abandon'd Times. Economy and Society, 30(2), 255-270.

Foucault, M. (1978). The History of Sexuality, vol. I. New York: Pantheon Books.

Foucault, M. (1984). Right o.f Death and Power over Life. The Foucault Reader (ed. P. Rabinow). New York: Pantheon Books.

Foucault, M. (1997). Michel Foucault: An Interview by Stephen Riggins. The Essential Works of Michel Foucault: 1954-1984, vol. I (ed. P. Rabinow). New York: The New Press.

Foucault, M. (2003a). Society Must Be Defended. New York: Picador.

Foucault, M. (2003b). The Birth of the Clinic: An Archaeology of Medical Perception. London: Routledge.

Genel, K. (2006). The Question of Biopower: Foucault and Agamben. Rethinking Marxism, I8 (I), 43-62.

Gillon, R. (1969). Suicide and Voluntary Euthanasia: Historical Perspective. Euthanasia and the Right to Death: The Case for Voluntary Euthanasia (ed. A. B. Downing). London: Peter Owen.

İnceoğlu, S. (1999). Ölme Hakkı. İstanbul: Ayrıntı Yayınları.

Jacobs, J. (I899). The Dying of Death, Fortnightly Review, New Series 72, 264-9.

Lazzarato, M. (2002). From Biopower to Biopolitics, Pli, I3, 99-II3.

Lamb, D. (1985). Death, Brain Death and Ethics. London and Sydney: Croom Helm.

Lemke, T. (2005). “A Zone of Indistinction” - A Critique of Giorgio Agamben's Concept of Biopolitics. Outlines. Critical Practice Studies, [online] 7(I), 3-13.

Lemke, T. (20II). Biopolitics: An Advanced Introduction. New York: New York University Press. 
Mills, C. (2008). The Philosophy of Agamben. Durham: Acumen Publishing.

Orford, A. (2007). Biopolitics and the Tragic Subject of Human Rights. The Logics of Biopower and the War on Terror (ed. E. Dauphinee \& C. Masters). New York: Palgrave Macmillan.

Rancière, J. (2004). Who is the Subject of the Rights of Man?. The South Atlantic 2uarterly, IO3(2), 297-310.

Patton, P. (2007). Agamben and Foucault on Biopower and Biopolitics. Giorgio Agamben: Sovereignty and Life (ed. M. Calarco \& S. DeCaroli). Stanford, Calif.: Stanford University Press.

Ryan, A.; Morgan, M. \& Lyons, A. (20II). The Problem with Death: Towards A Genealogy of Euthanasia. Doing Psychology: Manawatu Doctoral Research Symposium, 43-48.

Szerletics, A. (20II). Paternalism and Euthanasia: The Case of Diane Pretty before the European Court of Human Rights. Diritto e Questioni Pubbliche: $R i$ vista di Filosofia del Diritto e Cultura Giuridica Maniaci (ed. G. Pino \& A. Schiavello). 479-496.

Walter, T. (1994). The Revival of Death. London: Routledge. 
Öz: Bu yazıda, ölmenin ve öldürmenin özel biçimlerinin yașam ve ölüm arasındaki karanlık bir bölgede veyahut bulanık bir sınırda meydana geldiği gerçeğini göz önünde bulundurarak, ötenazi olgusu üzerinden, Michel Foucault (yașam politikası) ve Giorgio Agamben'in (ölüm politikası) biyopolitika kavramsallaștırmaları arasında bir orta yol bulmayı deneyeceğim. Bu doğrultuda, tarihsel bir arka plan sunmanın elzem olduğuna inandığım çalışmaya, egemen iktidarın bugünkü felsefi temellerini aldığı ve teorik doğrulamalarını sağladığı mevcut hukuki-tıbbi-siyasi kompleksi anlamak için, ötenazi ve intiharın kısa bir tarihi ile başlayacak; ve iktidar ile ölüm arasındaki ilișkinin her daim oldukça sorunlu olduğunu göstereceğim. İkinci olarak, Foucaultcu biyopolitika bağlamında ölümün ortadan kaybolușunun anlam[lar]ına yoğunlașacak ve Foucault'nun düșüncesinin aksine, Batı'da yirminci yüzyllın ortalarından itibaren ölümün yeniden-keșfedilmesine benzer bir durumun gerçekleștiğini öne süreceğim. Ve nihayet makalenin üçüncü ve son kısmında, ötenazi sorunundan hareketle, Agamben'in yașanmaya değmeyen hayat kavramını takdim ederek, Foucault'nun biyopolitika düşüncesindeki eksi[kli]ği, yani ölüm politikasını, tamamladığını ileri süreceğim.

Anahtar Kelimeler: Hekim destekli intihar, ölüm, ötenazi, biyopolitika, ölümpolitikası, iktidar, egemenlik.

${ }^{\left[{ }^{*}\right]}$ This paper is partially based on my article entitled "Türkiye'de Biyopolitikanın Ölü Doğuşu: Türkçe Akademik Yazın Alanında Biyopolitika Kavramının Alımlanma Biçimleri” [The Still Birth of Biopolitics in Turkey: The Reception of the Concept of Biopolitics in the Turkish Academic Literature], which appeared in Modus Operandi: Fournal of Relational Social Sciences, Issue 2, July 2015. 